\title{
Effect of goat milk fortification on chemical, microbial and sensorial quality characteristics of Paneer
}

\author{
A.L. SUPEKAR, S.G. NARWADE, SYED IMRAN HASHMI AND R.P. KADAM
}

\begin{abstract}
The present investigation was carried out to assess the suitability of goal milk incorporation in preparation of Paneer on the basis of sensorial properties and to observe the effect of goat milk addition of nutritional and microbial quality of Paneer. Different proportions of goat milk (viz., 25, 50 and 75\%) were used as replacement of buffalo milk and effect of different proportions on sensorial quality characteristics, chemical composition and microbial profile was evaluated. The Results showed that increasing proportion of goat milk incorporation reduced sensorial, nutritional and microbial quality of Paneer. However, results of overall acceptability showed that sample containing 25 per cent goat milk observed to be under very much liked sample among the other treatments without significantly affecting the sensory quality profile of Paneer.
\end{abstract}

KEY WORDS : Paneer, Goat milk incorporation, Nutritional quality, Microbial quality

How to CITE THIS PAPER : Supekar, A.L., Narwade, S.G., Hashmi, Syed Imran and Kadam, R.P. (2014). Effect of goat milk fortification on chemical, microbial and sensorial quality characteristics of Paneer. Res. J. Animal Hus. \& Dairy Sci., 5(2) : 131-135.

\section{MEMBERS OF RESEARCH FORUM}

Address for correspondence :

S.G. Narwade, Department of Animal Husbandry and Dairy Science, College of Agriculture, Vasantrao Naik Marathwada Krishi Vidyapeeth, PARBHANI (M.S.) INDIA

Email : narwades@ rediffmail.com

Associated Authors' :

A.L. Supekar, Department of Animal Husbandry and Dairy Science, College of Agriculture, Vasantrao Naik Marathwada Krishi Vidyapeeth, PARBHANI (M.S.) INDIA

Syed Imran Hashmi, Department of Food and Industrial Microbiology, College of Food Technology, Vasantrao Naik Marathwada Krishi Vidyapeeth, PARBHANI (M.S.) INDIA

R.P. Kadam, Department of Extension Education, College of Agriculture, Vasantrao Naik Marathwada Krishi Vidyapeeth, PARBHANI (M.S.) INDIA$$
\text { : }
$$ 